\title{
Comment on Continental Criminal Procedure
}

\author{
Abraham S. Goldstein $\dagger$ and Martin Marcus $\ddagger$
}

In December 1977, we published in this Journal the results of a study we had made of Continental criminal procedure. ${ }^{1}$ We noted that in the face of a new concern in the United States for overly broad prosecutorial discretion, a growing mistrust of plea bargaining, and a continuing doubt of the effectiveness of exclusionary rules, American commentators had begun to turn to so-called "inquisitorial" systems for guidance. The literature then available in English described many of these systems as operating without prosecutorial discretion or with discretion carefully controlled, functioning without guilty pleas, and providing a full pretrial judicial (or quasi-judicial) investigation for serious cases. We were concerned that this literature might be misleading-that it might have described only how the codes of criminal procedure provided that these systems should operate, and not how they actually do. ${ }^{2}$ We decided to explore these issues by interviewing prosecutors, judges, defense attorneys, and scholars in France, Germany, and Italy. In reporting the results of those interviews, we hoped to stimulate the attitude of critical inquiry so crucial to any "borrowing" from the institutions of another country. We also wanted to encourage the development of a more detailed body of knowledge of the operation of these systems.

$\dagger$ Sterling Professor of Law, Yale Law School.

$\mp$ Research Fellow, Yale Law School, 1975-76. Member, New York Bar.

1. A. Goldstein \& Marcus, The Myth of Judicial Supervision in Three "Inquisitorial" Systems: France, Italy, and Germany, 87 YALE L.J. 240 (1977) [hereinafter cited without cross-reference as Myth of Judicial Supervision].

2. Professors Langbein and Weinreb chide us because we did not review the literature written abroad. Langbein \& Weinreb, Continental Criminal Procedure: "Myth" and Reality, 87 YALE L.J. 1549, 1567 \& $\mathrm{n} .71$ (1978) [hereinafter cited without cross-reference as Continental Criminal Procedure]. They overlook the fact that we relied heavily on the writings of Langbein himself, which draw copiously on such literature, and on the writings of other acknowledged authorities (e.g., Professors Damaska, Jescheck and Herrmann). All draw heavily on the foreign literature. Our objective was to present a composite portrait of what had been communicated to Americans about those systems. In addition, we interviewed in detail leading academic authorities in each of the countries studied and, in order to get a sense of the law in operation, conducted extensive interviews with judges, public prosecutors, and defense counsel. See Myth of Judicial Supervision at 240 n.*, 246 n.17. It should be noted that Langbein and Weinreb give no indication of the empirical basis for their many assertions about how French or German law in fact operates. And the foreign literature they cite, Continental Criminal Procedure at $1567 \mathrm{n.71}$, does not include any specific reference to empirical studies that address problems of the sort we raise. We have not seen a copy of Dr. Weigend's bibliography, but he was among the persons we interviewed in detail and whose generous assistance we acknowledged, see Myth of Judicial Supervision at $240 \mathrm{n}$.". 
From our interviews, we concluded that judges in "inquisitorial" systems do not control or supervise the investigation, prosecution, or trial of most criminal cases much more closely than do judges in our own "adversarial" systems. We found that investigation was generally left to the police and that-despite statutory prohibitions to the contrary-charging discretion was exercised frequently and without significant supervision by both police and prosecutor. Although plea bargaining as such does not take place, we found analogous processes by which prosecutor and defendant made similar accommodations through "tacit understandings or patterns of reciprocal expectation."3

In their response to our article, Professors Langbein and Weinreb regrettably seem to be more committed to presenting a formalistic view of European procedures than to communicating how such procedures work and the extent to which they may deviate from formal requirements. Their appraisal of French and German procedure reflects little of the skepticism about the relation between law on the books and law in action that they undoubtedly would bring to bear in discussing American criminal procedure. Seeing the seeds of domestic reform in practices abroad, they ignore elements that might call some of those reforms into question. ${ }^{4}$ In this respect, they may be even more bound to formalism than many European observers. As happens all too often, the acolytes may be more faithful than the priests. ${ }^{5}$

3. Myth of Judicial Supervision at 279.

4. Conlinental Criminal Procedure at 1550; see J. Langbein, Comparative Criminal Procedure: Germany I-2 (1977); L. Weinreb, Denial of Justice 11-12, 42-43, 117-46 (1977).

5. Professor Damaska comments:

There is a good and amusing book waiting to be written on this frequent peeking over the fences of one's own national system into the legal garden of another, where the grass frequently seems greener. ... [I]t must be noted that much more empirical research on various aspects of the judicial system has been carried out in America than in other countries. Scholars from abroad, in describing their own system, quite frequently talk about the normative design. Such normative accounts are sometimes accompanied by more or less educated empirical guesses and very rarely by actual empirical studies with a well-designed methodology. There is thus the danger that Americans will compare their domestic realities with idealized descriptions of foreign systems ....

M. Damaska, A Foreign Perspective on the American Judicial System (working paper for conference on "State Courts: A Blueprint for the Future," held in Williamsburg, Va., March 19-22, 1978) (on file with Yale Law Journal); accord, W. Felstiner \& A. Drew, European Alternatives to Criminal Trials and Their Applicability in the United States 38 (Dec. 31, 1976) (National Institute for Law Enforcement and Criminal Justice Report) ("Pcrhaps it should come as no surprise that American critics see more hope in German solutions than do German observers. In most reform efforts, the closer you are to the details, the less sanguine you are about the effects.") Compare the Langbein and Weinreb statement that we have presented "no evidence that the German rule of compulsory prosecution is anything less than completely effective," Continental Criminal Procedure at 1563, with the statement of Professor Herrmann, quoted by us in $M y t h$ of Judicial Supervision at 282 n.95, that acknowledges the existence of "some examples of discre- 
Although Langbein and Weinreb assert that we have not fairly described the operation of the French and German systems, they do not challenge our central findings. For example, they concede that in France cases are "correctionalized"-treated as délits though chargeable as crimes-"in order not to burden the process" with unnecessary judicial investigations. ${ }^{6}$ They admit that "ordinary crimes" are routinely investigated in France only by the police and that the prosecutor usually relies on the evidence he receives from them. ${ }^{7}$ And they do not contest our view that most French trials are perfunctory proceedings in which " the key to the sufficiency of the evidence and accuracy of the charge lies more in the dossier than in the trial itself." "8 Similarly, they do not challenge our contention that German criminal investigations are dominated by the police, ${ }^{9}$ that uncontested trials are shorter than contested ones, and that " " $\mathrm{i}] \mathrm{f}$ there is no apparent reason for the judge to question a witness closely and if there is no encouragement from counsel or the parties for him to do so, the result is a trial that is not especially probing and is unlikely to stray far from the dossier." "10

We were concerned that the failure of the American and English literature on Continental criminal procedure to describe when and what summary procedures were employed would mislead Americans into believing that on the Continent summary procedures were somehow not necessary. Langbein and Weinreb do not charge us so much with inaccurately describing these procedures ${ }^{11}$ as with mischaracter-

tionary power that are not expressly authorized by the Code of Criminal Procedure" and observes: "[i]t can be argued that the development of these exceptions indicates that the German system works effectively only because of this unofficial police and prosecutorial discretion." Herrmann, The Rule of Compulsory Prosecution and the Scope of Prosecttorial Discretion in Germuny, 41 U. CHI. L. REv. 468, 505 (1974).

6. Continental Criminal Procedure at $\mathbf{1 5 5 2 .}$

7. Id. at 1553.

8. Id. at 1556 (quoting Myth of Judicial Supervision at 268).

9. Continental Criminal Procedure at 1559, 1564; accord, Kaiser, The Significance of Empirical Research into the State Prosecutor's Office for Criminology and for Legal Policy, in United Nations Asia and Far Elst Institute, Report for 1976 and Resource Material Series No. 13, at 72, 81-82 (1977) (except for economic crime, investigations by German State Prosecutors themselves are very unusual; prosecutor's evidence "is predetermined by and even dependent on the results of the police investigations").

10. Continental Criminal Procedure at 1566-67 (quoting Myth of Judicial Supervision at 266) (footnote omitted). Compare Continental Criminal Procedure at 1562 n.50 (citing study showing difference in duration of contested and uncontested trial is not substantial) with Myth of Judicial Supervision at $268 \mathrm{n} .68$ (criticizing methodology of study and suggesting that difference in duration of contested and uncontested trials is greater than indicated in study).

11. To some extent Langbein and Weinreb do charge us with inaccuracies, particularly through omission. Most broadly, they say that we ignore significant differences between the individual countries, a claim which is belied by the care we took to treat each country separately in our descriptions. More particularly, they state that we have omitted mention of the Zwischenverfahren, a German procedure for review of the sufficiency of the evidence 
izing them. They are troubled, for example, when we analogize French "correctionalization" and the German penal order to American plea bargaining and when we find in uncontested Continental trials striking similarities to the taking of guilty pleas in the United States. They assert that we measure these summary procedures (along with comparable Italian devices) against an unrealistic yardstick of judicial supervision of the entire criminal process and that we unfairly suggest that these common-sense shortcuts are either unlawful or improper deviations from an "inquisitorial" norm.

Our point, however, was not to criticize summary procedures. ${ }^{12}$ Like Langbein and Weinreb, we realize that not all cases can or should receive a thorough judicial investigation and trial. Our purpose was to explain the ways in which Continental systems respond to problems like those we face in the United States and the extent to which their summary procedures may serve similar ends. ${ }^{13}$ Our critics resist this

by the trial judge before trial. Continental Criminal Procedure at 1562 n.51. We noted the availability of this procedure but suggested that, as usually employed, it is ineffective. Myth of Judicial Supervision at 261-62. Langbein and Weinreb also quarrel with a statistic we cite from a study not published at the time our article appeared, indicating that, in $1970,68 \%$ of all reported cases in Germany were terminated for lack of evidence. We suggested that this figure pointed to "the exercise of some charging discretion by the prosecutor." Id. at 275 . Langbein and Weinreb note that "[t] not cleared were relatively less serious misdemeanors affecting unguarded property for which it is difficult to obtain evidence." Continental Criminal Procedure at 1564. The authors do not explain whether a case is "cleared" by a finding that although a particular person committed the offense, it cannot be proven. Nor do they say what the "clearance" rate is for the more serious offenses in which suspects are more likely to be identifiable. In short, the statistics cited by Langbein and Weinreb also plainly indicate that some charging discretion is exercised. The Max Planck Institute study, whose findings we described, Myth of Judicial Supervision at 275-76, and which they curiously dismiss as "unpublished and unofficial," Continental Criminal Procedure at 1564, confirms that such discretion is exercised.

12. At many points in their response, Langbein and Weinreb assume that we were critical of Continental practices that deviated from the Code. For example, they say that we "strongly intimate that, at least at a theoretical level, the failure to conduct a judicial investigation in most if not all [French] cases is improper and to be regretted," Continental Criminal Procedure at 1552 (footnote omitted). In discussing our observation that investigations by the French police are usually conducted without supervision by the prosecutor or examining magistrate and without subsequent judicial review, the authors speak of our "apparent disapproval of French police practices," id. at 1555. We expressed no approval or disapproval; we merely recognized the disparity between the law on the books and the law in action. It should be noted that Amcrican scholars frequently assume that the American system deviates from its formal requirements. The writing on European systems, however, reflects the contrary assumption that differences between practices and formal requirements are bad and to be avoided. This attitude may explain the reluctance to develop an empirical literature that searches for such differences.

13. Langbein and W'einreb apparently agree on the importance of knowing how these summary procedures work. They say, for example, that "the question we ought to ask [is] whether the procedure actually provided in France for the large number of delits [which do not receive a judicial cxamination] is preferable to ours in comparable cases." $I d$. at 1553. 
analysis. They admit that the French prosecutor "correctionalizes" cases to relieve the system of the obligation to conduct unnecessary judicial examinations, but, paradoxically, they claim that "his decision to do so does not evade a required procedure."14 They assume that because French prosecutors and defendants do not explicitly bargain over "correctionalization" or make other promises to exchange cooperation for leniency, the "seriousness of the accusation [in France] does have a bearing on the process of the prosecution," while in the United States it does not. ${ }^{15}$ This assertion errs in both directions: French "correctionalization" plainly allows factors other than the seriousness of the charge to affect the mode of prosecution; just as plainly, the seriousness of the charge in the United States is critically important to the scope of any bargaining that takes place about the plea or sentence.

The authors similarly resist the implications of their own observations about the German system. Though they assume as we do that not all cases are fully investigated and that the decision of how fully to investigate turns on the seriousness of the crime involved, ${ }^{10}$ they insist nonetheless that there is no evidence that "the German rule of compulsory prosecution is anything less than completely effective." 17 Of course, police may investigate all crimes they know they can solve, and prosecutors may prosecute all crimes for which they know there is supporting evidence. But questions inevitably arise concerning when such knowledge exists and how persistently such knowledge should be sought; our evidence suggests that such subtleties are exploited.

Finally, Langbein and Weinreb deny that either the German penal order or the summary trials in France or Germany can be compared to a bargained plea of guilty. They assert-although there is evidence to the contrary-that an accused who refuses to accept a German penal

14. Id. at 1552. Of course that procedure would be "required" if the offense were treated as a crime, and is not "required," and therefore not "evaded," only because the prosecutor decides to treat it as a ditit. By saying, as they do, that "persons charged with délits are not denied an investigation they ought to have had," $i d$., Langbein and Weinreb admit the utility of, and perhaps the need for, an extra-legal excrcise of discretion.

15. Id. at 1557. According to Langbein and Weinreb, "it would startle all of those involved, the accused not least, to suggest that he has given up something when he does not insist on being prosecuted for a more serious offense." Id. American defondants who plead guilty to reduced charges understand full well that they are "giving up something" by not putting the prosecution to its proof on the higher charges. French defendants and defense counsel, who glean from their experience a relationship between cooperation and "correctionalization," understand as well.

16. In doing so, they discount entirely an empirical study whose findings of widespread discretion exercised by police and prosecutor we reported. See note 11 supra (discussing study by Max Planck Institute).

17. Continental Criminal Procedure at 1563. 
order will not receive a higher sentence if convicted at trial, ${ }^{18}$ and they note that since "German trial procedure is relatively rapid, . . . the prosecutor has no particular incentive to try to avoid trial even if he could."10 One reason why trials are rapid is that in most of them the accused does not contest his guilt. ${ }^{20}$ Langbein and Weinreb nowhere deny that in both France and Germany such cooperation is appreciated and rewarded. In general they assume that because there is no explicit bargaining, face-to-face or otherwise, there are also no trade-offs and compromises. Such an assumption simply mistakes the surface, and the formal law, for the underlying reality.

The authors also maintain that we "dismiss as insignificant all the differences in the selection, training, and professional codes" of police and prosecutors, "as well as the institutional structure within which they work." ${ }^{21}$ We do not recognize, they say, that these officials can be fairly said to serve "judicial" functions, that dossiers prepared by the judicial police are something more than American police reports, and that judgments made by Continental prosecutors-even when made beyond the confines of the codes that regulate their conduct-are more evenhanded than comparable decisions by their American counterparts. With this criticism, the authors reveal that at bottom they do not rely on differences between "inquisitorial" and "adversarial" procedure but instead on the very point we affirm, that "[i]n the end these Continental systems rely more on their ideology, and on the assumption that officials adhere to the ideology, than on detailed judicial supervision."'22 Our prosecutors, like those in Continental systems, are charged with the duty of uncovering exculpatory as well as inculpatory

18. Id. at 1565. But see H. Bruns, StrafzumessungsRecht 607 (2d cd. 1974) ("Zwar werden die durch Strafhefehl ausgeworfenen Strafen im Falle fruchtlosen Einspruchs oft crhöht; nach Seibert . . . scheint geradezu ein entsprechender (unzulässiger) Gerichtsgebrauch dieser Art zu bestehen, gegen den die Revisionsgerichte aber nicht eingreifen können, sofern der Tatrichter nicht so unvorsichtig ist, die Tatsache des Einspruchs ausdrücklich als Strafschärfungsgrund anzugeben . . . (translated thus: "In fact, penalties stemming from the penal order are frequently increased in the case of a fruitless objection; according to Seibert there seems almost to be a corresponding [unlawful] judicial practice against which appellate courts cannot react so long as the trial judge is not careless enough to explicitly mention the fact of the objection [to the penal order] as a ground for increasing the severity of punishment ....")); W. Felstiner \&. A. Drew, supra note 5, at 55-56 ("'[S]everal government officials, legal academics, and legal sociologists whom we interviewed believe that defendants frequently bargained over penal orders. Their suspicions are based on the high proportion of penal orders in white collar offenses; their observation of cases where suspension of a driver's license is a possibility; and the implication in Dass's Handbook for Lawyers, a widely-used practical text, that discussion of a penal order can be initiated by a defendant's lawyer.")

19. Continental Criminal Procedure at 1562.

20. See note 10 supra.

21. Continental Criminal Procedure at $\mathbf{1 5 5 0 .}$

22. Myth of Judicial Supervision at 283. 
evidence. Our police, like theirs, are bound by law ${ }^{23}$ and face disciplinary proceedings and civil and criminal penalties when they violate it. ${ }^{24}$ Naked assertions that Continental officials are more committed ideologically or institutionally to the rule of law do not advance the debate on the merits of borrowing inquisitorial procedures. ${ }^{25}$

We are not hostile to the redefinition of the judicial role in the American system. Indeed, one of us wrote earlier that in the United States

we are held captive by models built on the adversary trial. Yet it makes little sense to carry the idea of a reactive judge in an adversary trial to the quite different context of the judge who must supervise administrative processes. Adversary processes and accusatorial premises may be inapplicable to a system which has changed its shape and which increasingly casts the judge in a proactive role. We might better be served by practices drawn from inquisitorial systems, in which judges are routinely assigned tasks which are administrative and supervisory. ${ }^{20}$

We looked to Continental criminal procedure precisely because it is there that a more active and effective judicial role is claimed. But our findings suggest the need to learn the limits of what judges and other

23. As Langbein and Weinreb say of the German police forces, Continental Criminal Procedure at 1560 , so might it be said of many of ours, particularly in large citics or at the federal level: they "are relatively large; they are organized or coordinated" in a hierarchical manner, "and they have many grades of rank and compensation." "[M]eritocratic promotion policies" that give the police "a direct incentive to avoid generating citizen complaints" are also to be found in our system. Such generalizations, of course, tell us very little about actual law enforcement in particular jurisdictions.

24. It does not prove much to describe a single instance of the prosecution seventeen years ago of a police official for abusing a suspect during interrogation. See Continental Criminal Procedure at 1560 (discussing case of Otto $\mathrm{N}_{2}$ ). Occasional examples of successful civil and criminal proceedings against American police officers could be cited as well. See Newman, Suing the Lawbreakers: Proposals to Strengthen the Section 1983 Damage Remedy for Law Enforcers' Misconduct, 87 XALE L.J. 447, 449-5I (1978) (citing civil and criminal cases and criticizing their effectiveness as deterrent).

25. We found that the French authorities are reluctant to invoke another technique for remedying police misconduct, the "nullification" of illegal investigatory acts by striking the evidence so produced from the dossier. Commenting on our observation, Langbein and Weinreb assert that "the exclusion of evidence is not applied as a remedy for police misconduct in France as it is here," Continental Criminal Procedure at 1554 . We were not, as the authors suggest, charging the French system with failing to adopt the full range of exclusionary rules applicable in this country but simply reporting that French judges charged with supervising investigations and conducting trials do not enforce the "nullification" provisions of the code. See Myth of Judicial Supervision at 254-55. The issue is not one of judicial creation of a remedy through the exclusionary rule, but of judicial failure to apply the statutory remedy of nullification.

26. A. Goldstein, Reflections on Two Models: Inquisitorial Themes in American Criminal Procedure, 26 Stan. L. Rrv. 1009, 1024 (1974). 
officials can do and to assess the risk that judicial control may drive decisions into hiding in the inevitable cracks among the provisions of a code of criminal procedure. We reported our findings not to end an interesting and potentially important debate, but instead to develop it further by encouraging the analysis of issues and the production of empirical evidence that might separate myth from reality. The response by Professors Langbein and Weinreb suggests that the myths persist and continue to intrude in appraising the significance of European procedures for American criminal justice. 


\section{The Yale Law Journal}

Volume 87, Number 8, July 1978

\section{Paul M. Smith \\ Editor-in-Chief}

Charles King III

Managing Editor

Kim J. Landsman

Martha L. Minow

James F. Strnad II

Article \& Book Review

Editors
Sheldon S. Adler

Michael J. Album

Donald F. Brosnan

Peter C. Canfield

William W. Chip
Eric M. Freedman

A. Ann Fruman

Gary S. Katzmann

Bruce R. Kraus

John J. Kulewicz

Lee J. Levine
William L. Lynch

Joseph J. Sheehan

Michael G. Starr

Bruce C. Swartz

Ellen E. Wright

Secretaries to the Editors M. Olive Butterfield, Pamela Willmott

\section{Student Contributors to This Issue}

Sheldon S. Adler, Toward a Constitutional Theory of Individuality: The Privacy Opinions of Justice Douglas

Michael J. Album, Government Control of Richard Nixon's Presidential Material

Donald F. Brosnan, The Supreme Court's Use of Statutory Interpretation: Morris v. Gressette, APA Nonreviewability, and the Idea of a Legislative Scheme

Peter G. Canfield, The Federal Securities Laws and Employee Pension Participants: Retiring Daniel

Gary S. Katzmann, The Proposed Court-Appointed Special Prosecutor: In Quest of a Constitutional Justification

Lee J. Levine, The Editorial Function and the Gertz Public Figure Standard 